\author{
Tamara B. Sergeeva \\ Batdorj Oyunjargal \\ Irina A. Chepushtanova \\ Ilya S. Galanin \\ Ural Federal University, \\ Ekaterinburg, Russia
}

\title{
Biographical reflection and readiness to master age-related changes at a senior age*
}

Abstract. The article presents the results of an empirical study of psychological readiness to master age-related changes and biographical reflection in the elderly in the context of professional employment. A comparison of the level of biographical reflection and readiness for age-related changes in working and non-working pensioners was carried out, and the nature of the relationship between these phenomena was described.

Keywords: old age, biographical reflection, readiness to master age-related changes, professional employment.

Introduction. When studying mobility and professional health in seniors, the problem of the ratio of various components of psychological readiness for mobile behaviour is of great importance [1]. In this article, we will focus on the following question: what is the nature of the relationship between readiness to master age-related changes and biographical reflection in older people, if their level depends on professional employment. The readiness to master age-related changes is understood as an integrative mental formation which determines the person's awareness of the fact of their own aging and its acceptance, resulting in an active search for productive adaptation strategies [2]. Biographical reflection is defined as awareness and analysis of an individual's life path [3].

Materials and methods. The empirical study involved 272 residents of the city of Ekaterinburg and Sverdlovsk region (Russia) aged 55-80,

This study was funded by the Russian Foundation for Basic Research Grant № 19-013-00431. 
who participated in the study on a voluntary basis. Two groups were singled out for comparison: non-working pensioners (144 people aged 55-80, average age: 67), working pensioners (128 people aged 55-74, average age: 61 ). The two key methods were used: M.V. Klementyeva's method for assessing the level of biographical reflection development [4] and the "Readiness to Master Age-Related Changes" questionnaire by N. S. Glukhanyuk and T. B. Sergeeva [2]. We also conducted a comparative analysis by applying the Mann-Whitney U-test and correlation analysis by using Spearman's Rank Correlation Coefficient as statistical methods.

Results. When we applied professional employment as a criterion for comparison of older people, we found a number of differences in their biographical reflection. For example, working pensioners demonstrate higher indicators of reflection on the life of others $(U=10627, p=0.047)$ and their own life $(\mathrm{U}=11428, \mathrm{p}=0.001)$, in particular in cognitive $(\mathrm{U}=10982, \mathrm{p}=0.011)$ and personal components $(\mathrm{U}=11085.5, \mathrm{p}=0.007)$. They are more inclined to evaluate their life events from an "impersonal" position, focusing on the existential criteria communicated by society and culture. Working pensioners are more prone to analyzing their lives, rethinking life objectives, and evaluating life events.

The readiness to master age-related changes among working and non-working pensioners is at the same level. Differences were found only in two out of twenty indicators of readiness - the cognitive aspect of the social component and the motivational aspect of the professional component. Non-working older people are more aware of age-related changes associated with the changes in their social status and attitudes of others. Continuing professional activity slows down this process and at the same time stimulates the search for strategies for adapting to the changes that occur in labour activities and professional roles due to retirement. In general, it can be concluded that at an old age, professional employment is no longer a factor that has a decisive impact on the level of psychological readiness to master age-related roles and tasks. Development of such readiness can be considered a normative objective for elderly people. Continuing or completing one's career contributes only to certain professionally significant components of readiness.

The analysis of the relationship between biographical reflection and readiness for age-related changes showed a similar picture in subsa- 
mples of working and non-working pensioners. Therefore, the results of the correlation analysis will be described using the general sample. The main result is a positive correlation between the motivational level of readiness and the personal component of biographical reflection $(r=0.176, p=0.004)$. Elderly people able to understand the meaning of life events, influence their life path, independently and responsibly formulate life objectives are more active in looking for ways to cope with age-related changes: physiological $(r=0.264, p=0.000)$, social $(r=0.138$, $p=0.034)$, personality-psychological $(r=0.184, p=0.004)$, and professional $(\mathrm{r}=0.267, \mathrm{p}=0.000)$.

Conclusion. The study showed that still-working seniors are more likely to analyze their own life events and life paths of others. At the same time, the psychological readiness to master age-related changes at an old age does not significantly depend on professional employment. Regardless of professional employment, motivational readiness to seek and use strategies for mastering age-related changes positively correlates with the personal component of biographical reflection, which manifests itself in the analysis of life goals and meanings of events in one's life.

1. Sergeeva T. B., Pecherkina A. A., Glukhanyuk N. S., Borisov G. I. Lichnostnaya mobilnost kak prediktor professionalnogo zdorovya i blagopoluchiya v pozhilom vozraste // Perspektivy nauki i obrazovaniya. 2019. № 42(6). P. 397-408. [in Russian]

2. Glukhanyuk N. S., Sergeeva T. B. Psikhologiya pozdnego vozrasta: rezul'taty issledovaniy. Ekaterinburg: Rossijskij gosudarstvennyj professional'no-pedagogicheskij universitet, 2007. [in Russian]

3. Klementyeva M. V. Biograficheskaya refleksiya kak resurs samorazvitiya vzroslykh lyudey // Kul'turno-istoricheskaya psihologiya. 2016. № 12(1). P. 14-23. [in Russian]

4. Klementyeva M. V. Ponyatiye biograficheskoy refleksii i metodika yeye otsenki // Kul'turno-istoricheskaya psihologiya. 2014. № 10(4)). P. 80-93. [in Russian] 